\title{
EFFECT OF MORPHOLOGICAL AND PHYSIOLOGICAL TRAITS ON SEED YIELD AND OIL CONTENT IN SUNFLOWER
}

Hladni, N. ${ }^{*}{ }^{\text {, Jocić, }}$ S. ${ }^{1}$, Miklič, V. ${ }^{1}$, Mijić, A. ${ }^{2}$,

Saftić-Panković, D. ${ }^{1,4}$ and Škorić, D. ${ }^{3}$

${ }^{1}$ Institute of Field and Vegetable Crops, Maksima Gorkog 30,

21000 Novi Sad, Serbia

${ }_{2}^{2}$ Agricultural Institute Osijek, Južno predgrađe 17, 31001 Osijek, Croatia

${ }^{3}$ Serbian Academy of Sciences and Arts, Novi Sad Branch, Nikole Pašića 6,

21000 Novi Sad, Serbia

${ }^{4}$ EDUCONS University, Vojvode Putnika bb, 21208 Sremska Kamenica, Serbia

Received: May 5, 2010

Accepted: October 25, 2010

\section{SUMMARY}

Path coefficient analysis was used to separate direct and indirect effects of studied traits on seed oil content and seed yield, and to identify traits that could be used as selection criteria in sunflower breeding. Significant and highly significant correlations were found between most of the examined traits. Highly significant negative correlations have been established between stem diameter, total leaf area per plant, head diameter and 1,000-seed weight on one side and seed oil content on the other. Highly significant positive correlations have been established between seed yield on one side and stem diameter, total leaf area per plant, head diameter, total number of seeds per head, and the 1,000-seed weight on the other. The weight of 1,000 seeds had a highly significant direct negative effect on seed oil content and a highly significant direct positive effect on seed yield. The total number of seeds per head has demonstrated a highly significant direct positive effect on seed yield and oil content. The total leaf number per plant has demonstrated a significant direct positive effect on seed yield. A path coefficient analysis of seed yield at phenotypic level indicated that maximum direct effects were shownby the weight of 1,000 seeds, total number of seeds per head and total leaf number per plant. The total number of seeds per head was the most important trait that determined seed yield and oil content. The obtained results can be used in sunflower breeding programs aimed at the development of sunflower hybrids that combine high genetic potentials for seed yield and seed oil content.

Key words: Helianthus annuus, hybrid, morphological and physiological traits, correlation, seed yield, oil content

* Corresponding author: Phone: +381 214898 411; Fax: +380 216413 833;

e-mail: nada.hladni@ifvcns.ns.ac.rs 


\section{INTRODUCTION}

Sunflower is globally one of the most important oil crops and its oil is counted among the highest quality vegetable oils on the market (Škorić et al., 2007). In Serbia, sunflower is the main oil crop. The sunflower acreage varies from 160 to 210 thousand ha, with the seed yield ranging from 1.7 to $2.3 \mathrm{t} / \mathrm{ha}$. Considering the sunflower acreage, Serbia is in the seventh place in Europe and by yield level right behind France and Hungary (Miklič et al., 2007).

The increasing demand from growers on the local and the international market for higher quality and higher yielding sunflower hybrids calls for an immediate replacement of the currently grown hybrids with better, more productive and more stable ones (Miklič et al., 2010).

The main objectives of sunflower breeding at Institute of Field and Vegetable Crops in Novi Sad is the development of hybrids with a high genetic seed yield potential (above $5 \mathrm{t} / \mathrm{ha}$ ) and high seed oil content ( $>50 \%$ ), which would provide the oil yield per hectare of more than $2.5 \mathrm{t}$ (Miklič et al., 2008).

Seed yield and oil content are the two most important economic traits in sunflower. However, they are under a strong influence of environmental factors, they have a complex inheritance and low heritability. That is why the breeding for these complex traits demands knowledge of relationships among plant traits that affect their formation. When starting a breeding program, choice of parents is important for achieving both short and long term objectives.

Increasing seed yield and oil content is the top priority of most sunflower breeding programs. Breeding for high seed yield and seed yield components and development of new sunflower ideotypes demands an increased genetic variability which is accomplished by interspecific hybridization (Škorić et al., 2007). In sunflower breeding for high yield peformance, it is necessary to find morphological and physiological traits, which are easily improved and which show correlation with seed yield and oil content, so that they can be used as selection criteria (Hladni et al., 2008).

Relationships between seed yield and morphological and physiological traits are effectively studied by the simple correlation coefficient analysis (Škorić, 1974; Marinković, 1992; Hladni et al., 2006). As the simple correlation analysis cannot fully explain the relationships between traits, the path coefficient analysis is introduced for a more successful breeding work. This type of analysis enables to partition correlation coefficients to their components which in turn allows to distinguish a direct effect of one variable from indirect effects of other variables, thus giving a clear picture of the individual contribution of each variable to seed yield and oil content.

Total leaf area and plant height (Hladni et al., 2004), total seed per head (Gonzales et al., 2000) and 1,000-seed weight (Marinković, 1992; Gonzales et al., 2000) were found to extend positive direct effects on seed yield. 
The cultivated sunflower shows a significant variability in oil content, while the oil content in wild species is generally low (Seiler, 1992). Origin of plant material and weather conditions in the year of study have a high impact on seed oil content (Hladni et al., 2006).

Positive and highly significant relationships exist between seed oil content on one side and head diameter, number of seeds per head and 1,000-seed weight on the other (Marinković, 1988; Marinković et al., 1994).

In this paper, we studied mutual relationships between several morphological and physiological traits (stem diameter, total leaf number per plant, total leaf area per plant, plant height, and head diameter, total seed number per head, 1,000-seed weight) and seed yield and oil content in a group of new experimental sunflower hybrids.

\section{MATERIALS AND METHODS}

In this study we used 21 experimental hybrids developed from new divergent (A) $\mathrm{cms}$ inbred lines. The female inbred lines, developed by interspecific hybridization from various populations [NS-GS-1, NS-GS-2 (RES-834-1), NS-GS-3 (DEBSIL-3672), NS-GS-4, NS-GS-5 (PRA-RUN-1321-1), NS-GS-6, NS-GS-7 (DES-14742)] and restorer lines possessing good combining characteristics (RHA-R-PL-2/1, RHA-N-49, RUS-RF-OL-168) had been developed at Institute of Field and Vegetable Crops, Novi Sad.

The experiment was established at Rimski Šančevi experiment field of Institute of Field and Vegetable Crops, in a randomized complete block system with three replications, during two growing seasons. The soil in the experiment plots had $2.8 \%$ humus content, moderate contents of phosphorus and potassium and $\mathrm{pH} 6.92$ (Vasin et al., 2002).

The examined traits were analyzed in samples that consisted of thirty plants (ten plants per replication) sampled from inside rows of each block.

At the stage of physiological maturity, plant height $(\mathrm{PH})$ and head diameter (HD) were measured $(\mathrm{cm})$ in field. Plants at the flower stage were taken to the laboratory for measurements of the total leaf number per plant (TLN), stem diameter (STD; $\mathrm{cm}$ ), and total leaf area per plant (TLA; $\mathrm{cm}^{2} /$ plant). The last trait was measured with a leaf area meter (LI-300-LiCor, USA). After harvest, seed yield per individual plants (SY), produced in open pollination, was weighed in laboratory. The number of filled seeds per head (total seed number-TSN) was counted. The weight of 1,000 seeds (M1000S; g) was determined in a random sample of cleaned and air dried seed. Seed oil content (SOC) was analyzed non-destructively by the method of nuclear magnetic resonance (NMR). Mean values and correlation coefficients ( $r$ ) were determined according to Hadživuković (1991). Direct and indirect effects of the examined traits on seed yield were analyzed by the path coefficient analysis 
(Wright, 1921; Dewey, 1952; Ivanović, 1985). Statistical analysis was performed using MSTAT-C (1991) and SAS System Software (2003) programs.

\section{RESULTS AND DISCUSSION}

The main objective of sunflower breeding is to develop new hybrids with a high genetic potential for seed yield and oil content. Additional information are still needed to clarify relationships between seed oil content, seed yield and their components. Correlations between different traits are an aspect that should be kept in mind for better planning of breeding programs in sunflower.

Table 1: Simple correlation coefficients of seven yield components and their effects on seed yield and oil content in sunflower.

\begin{tabular}{|c|c|c|c|c|c|c|c|c|c|}
\hline \multirow{2}{*}{ Trait } & & TLN & TLA & $\mathrm{PH}$ & HD & TSN & M1000S & SOC & SY \\
\hline & & $\mathrm{X} 2$ & $\mathrm{X3}$ & $\mathrm{X} 4$ & $\mathrm{X} 5$ & $\mathrm{X} 6$ & $\mathrm{X} 7$ & $\mathrm{Y} 1$ & Y2 \\
\hline STD & $\mathrm{X} 1$ & $-0.514^{\star \star}$ & $0.776^{\star \star}$ & $-0.456^{\star \star}$ & $0.642^{\star \star}$ & $0.038^{n s}$ & $0.379^{*}$ & $-0,419^{\star \star}$ & $0.411^{\star \star}$ \\
\hline TLN & $\mathrm{x} 2$ & & $-0.202^{n s}$ & $0.566^{\star \star}$ & $-0.452^{\star \star}$ & $-0.075^{n s}$ & $0.010^{\mathrm{ns}}$ & $0.168^{\mathrm{ns}}$ & $0.087^{\mathrm{ns}}$ \\
\hline TLA & X3 & & & $-0.161^{n s}$ & $0.602^{\star *}$ & $0.253^{\star}$ & $0.461^{\star \star}$ & $-0.457^{\star *}$ & $0.623^{\star \star}$ \\
\hline $\mathrm{PH}$ & $\mathrm{X} 4$ & & & & $-0.544^{\star *}$ & $0.040^{\mathrm{ns}}$ & $0.220^{\mathrm{ns}}$ & $-0,009^{n s}$ & $0.200^{\mathrm{ns}}$ \\
\hline HD & $\mathrm{X} 5$ & & & & & $0.297^{*}$ & $0.291^{*}$ & $-0.588^{\star *}$ & $0.446^{\star \star}$ \\
\hline TSN & $\mathrm{X} 6$ & & & & & & $-0.164^{n s}$ & $0,091^{\mathrm{ns}}$ & $0.369^{\star \star}$ \\
\hline M1000S & $\mathrm{X} 7$ & & & & & & & $-0.786^{\star *}$ & $0.790^{\star \star}$ \\
\hline
\end{tabular}

${ }^{\star *} \mathrm{~F}$ test significancy at level $\mathrm{P}<0.01{ }^{*} \mathrm{~F}$ test significancy at level $\mathrm{P}<0.05$ ns- not significantly different

\begin{tabular}{llll}
\hline X1 & Stem diameter (STD) & X6 & Seed number per head (TSN) \\
X2 & Total leaf number per plant (TLN) & X7 & Weight of 1000 seeds (M1000S) \\
X3 & Total leaf area per plant (TLA) & Y1 & Seed oil content (SOC) \\
X4 & Plant height (PH) & Y2 & Seed yield per plant (SY) \\
X5 & Head diameter (HD) & & \\
\hline
\end{tabular}

The analysis of simple correlation coefficients showed that very high correlations existed between the 1000 -seed weight $\left(-0.786^{* *}\right)$, head diameter $\left(-0.588^{* *}\right)$, total leaf area per plant $\left(-0.457^{* *}\right)$, stem diameter $\left(-0.419^{* *}\right)$ on one side and seed oil content on the other. Very high positive correlations were found between these traits $\left(0.790^{* *} ; 0.446^{* *} ; 0.623^{* *} ; 0.411^{* *}\right.$, respectively) and seed yield per plant. These results are in agreement with those of Punnia and Gill (1994), who found a significant negative correlation between the 1,000-seed weight and seed oil content. However, our results disagree with those of Marinkovic et al. (1994), who found a highly significant positive correlation between seed oil content on one side and head diameter, total seed number per head and 1,000-seed weight on the other. Highly significant correlations were found between seed yield per plant and the 1,000-seed weight (Yalcin et al., 2007; Behradfar et al., 2009), total leaf area per plant (Merrien et al., 1982; Hladni et al., 2001), and head diameter (Hladni et al., 2003; Mijić et al., 2006; Thitiporn, 2008). A positive relationship between seed yield and stem 
diameter was reported by Punnia and Gill (1994), Ashok et al. (2000) and Ozer et al. (2003).

Simple correlation coefficients showed that the total leaf number per plant and total seed number per head exhibited a positive but low correlation with seed oil content $\left(0.623^{* *}\right)$ and a very high positive correlation with seed yield per plant $\left(0.369^{* *}\right)$. A low positive correlation was found between seed oil content and total seed number per head. This result is in agreement with those of Khan et al. (2005) who found a significant negative correlation between seed oil content and total seed number per head. The highly significant correlation between seed yield per plant and total seed number is in accordance with the resuls of Dagustu (2002) and Dušanić et al. (2004).

Plant height has exhibited a low negative correlation with seed oil content and a low positive correlation with seed yield per plant (Table 1). A low negative correlation was found between seed oil content and plant height. This result is in agreement with those of Arshad et al. (2007). Significant positive correlation was not established between plant height and seed yield per plant although it had been reported by other researchers (Marinković, 1992; Hladni et al., 2003; Mijić et al., 2006; Habib et al., 2007).

The analysis of path coefficients gave a much clearer picture of the effect of certain independent variables on seed yield and oil content in sunflower plants. This analysis allows to separate a direct effect of one variable from indirect effects of other variables. In this way we can see more clearly the actual contribution of individual variables to the forming of the final traits.

The weight of 1,000 seeds exhibited the highest direct negative effect on seed oil content and the highest positive direct effect on seed yield per plant $\left(\mathrm{DE}=-0.565^{* *}\right.$ and $\mathrm{DE}=0.789^{* *}$, respectively) which explains the very high correlations between these traits $\left(\mathrm{CC}=-0.786^{* *}\right.$ and $\mathrm{CC}=0.790^{* *}$, respectively; Figures 1 and 2$)$. The direct effect of the weight of 1000 seeds on seed oil content was decreased by the negative indirect effect of the former trait on head diameter $(\mathrm{IE}=-0.202)$. A very high positive direct effect of the weight of 1,000 seeds on seed yield per plant brought about a high direct effect of the weight of 1,000 seeds on seed yield per plant, while indirect effects of the weight of 1,000 seeds on seed yield per plant via the other traits were not significant. Many researchers such as Ozer et al. (2003) and Khan et al. (2005) also reported of having found a positive direct effect of the weight of 1,000 seeds on seed yield.

The highest positive direct effect on seed yield and oil content per plant was exhibited by the total seed number per head $\left(\mathrm{DE}=0.485^{* *}\right.$ and $\mathrm{DE}=0.204^{* *}$, respectively Figures 1 and 2). The simple correlation coefficient between total seed number per head and seed oil content was slightly lower than the direct effect. Their relationship was masked by the negative indirect effect of total seed number per head via head diameter $(\mathrm{IE}=-0.206)$ and by its positive indirect effect via the weight of 1,000 seeds $(\mathrm{IE}=0.093$ ). The effect of the simple correlation coefficient 
between total seed number per head and seed yield per plant was very high $\left(0.369^{* *}\right)$. The lower simple correlation coefficient than the direct effect resulted from the negative indirect effect of total seed number per head on seed yield per plant via the weight of 1,000 seeds (IE $=-0.129$ ). Škorić (1974), Marinković (1987), Patil et al. (1996), Lal et al. (1997), El-Hosary et al. (1999), Taklewold et al. (2000) and Dušanić et al. (2004) also reported positive direct effects of total seed number per head on seed yield. However, Merrien et al. (1982) reported a negative direct effect of total seed number per head on sunflower seed yield.

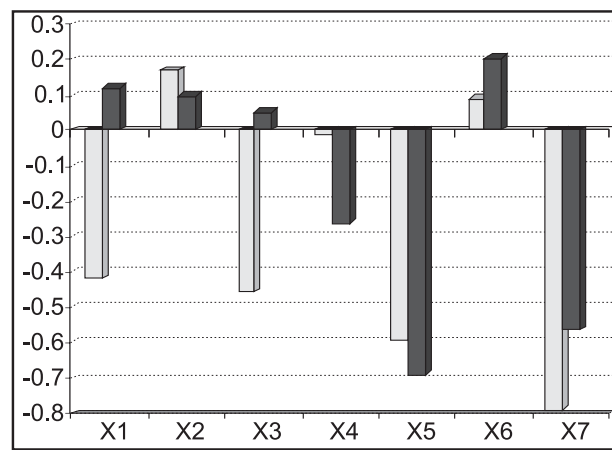

Figure 1: Simple correlation coefficients and direct effects of the seven yield components of seed oil content.

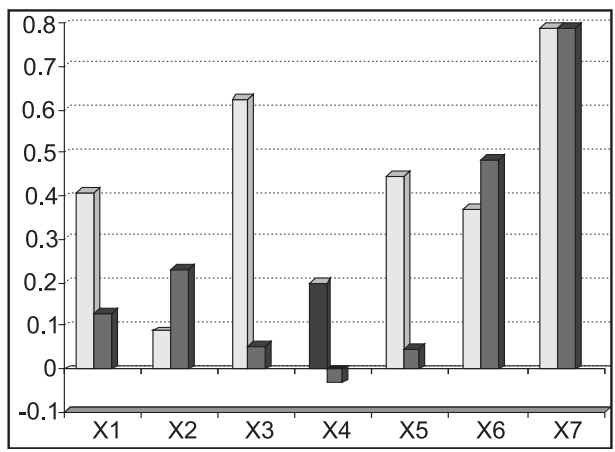

Figure 2: Simple correlation coefficients and direct effects of the seven yield components of seed yield.

\begin{tabular}{llll}
\hline X1 & Stem diameter (STD) & X5 & Head diameter (HD) \\
X2 & Total leaf number per plant (TLN) & X6 & Seed number per head (TSN) \\
X3 & Total leaf area per plant (TLA) & X7 & Weight of 1000 seed (M1000S) \\
X4 & Plant height (PH) & & \\
\hline
\end{tabular}

Head diameter had a very high negative direct effect on seed oil content ( $D E=-$ $0.692^{* *}$ ), with a very high negative simple correlation $\left(\mathrm{CC}=-0.588^{* *}\right.$ ), (Figures 1, 2). The simple correlation coefficient between head diameter and seed oil content was lowered by the negative indirect effect of head diameter via the weight of 1000 seeds $(\mathrm{IE}=-0.164)$ and a positive indirect effect of head diameter via plant height $(\mathrm{IE}=0.142)$. Although head diameter exhibited a very low positive direct effect on seed yield per plant $(\mathrm{DE}=0.047)$, the analysis of the morphological and physiological components of seed yield showed that the direct effect of head diameter on seed yield per plant was masked by the positive indirect effect of head diameter via the weight of 1000 seeds $(\mathrm{IE}=0.230)$, total seed number per head $(\mathrm{IE}=0.144)$ and the negative indirect effect of head diameter via total leaf number per plant (IE=-0.104). The resulting simple correlation coefficient between head diameter and seed yield per plant was very high $\left(\mathrm{CC}=0.446^{* *}\right)$. These results are in agreement with those of Green (1980), Sarno et al. (1992), Nirmala et al. (2000) and Fick et al. (1974) who found a negative direct effect of head diameter on seed yield per plant.

Plant height exhibited a high negative direct effect on seed oil content and a low negative direct effect on seed yield per plant $\left(\mathrm{DE}=-0.260^{*}\right.$ and $\mathrm{DE}=-0.031$, respec- 


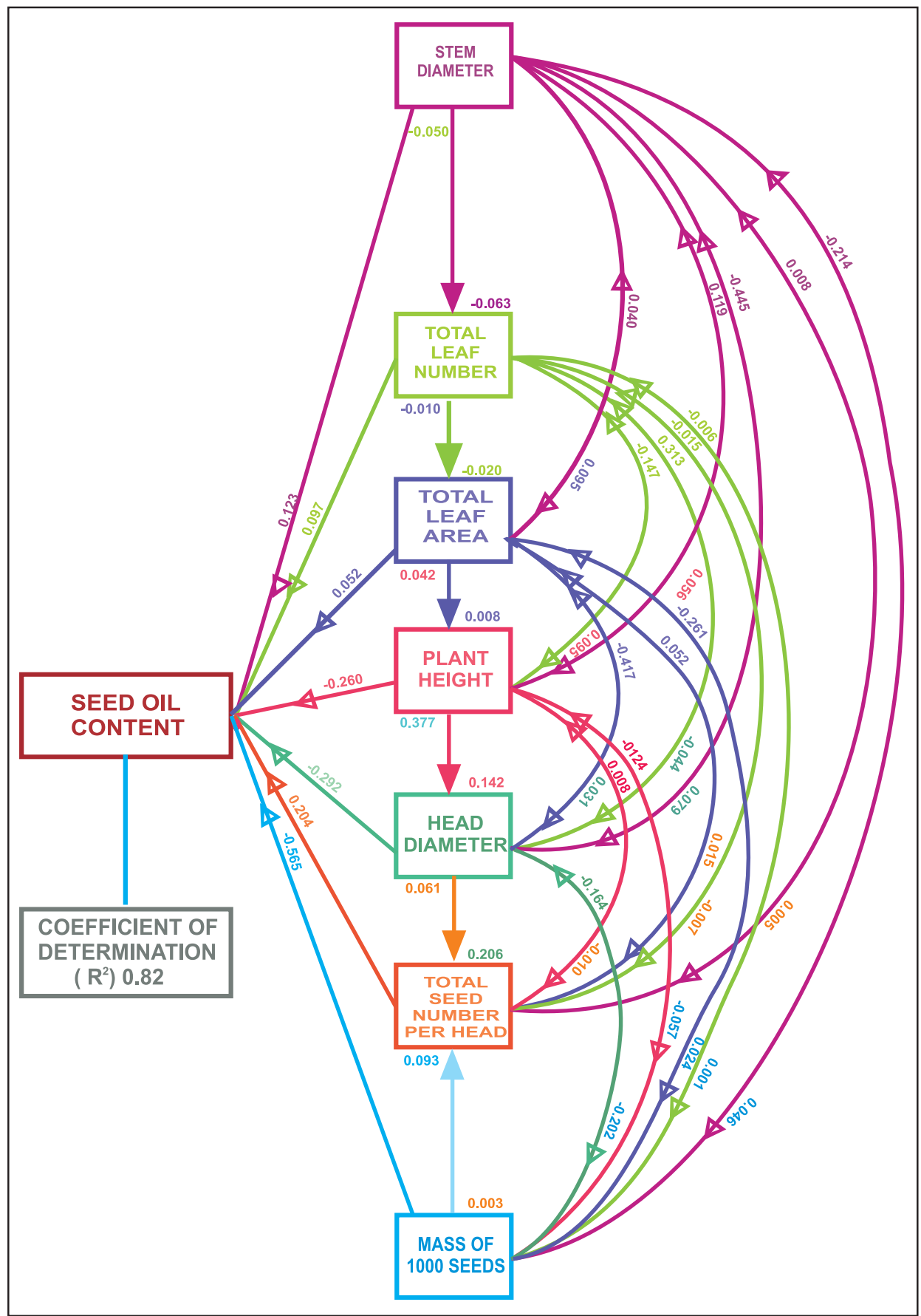

Figure 3: Graphic presentation of the path diagram for seed oil content in sunflower $\left(F_{1}\right)$ 
tively). Although the direct effect of plant height on seed oil content was high and negative, their simple correlation coefficient was very low and negative $(\mathrm{CC}=$ 0.009). The value of the simple correlation coefficient between plant height and seed oil content would have been higher were it not lowered by the positive indirect effect of plant height via head diameter $\left(\mathrm{IE}=0.377^{* *}\right)$ and by the negative indirect effect of plant height via the mass of 1,000 seeds $(\mathrm{IE}=-0.164)$. The simple correlation coefficient between plant height and seed yield per plant was low but positive $(\mathrm{CC}=0.200)$. The analysis of partial correlations coefficients showed that the direct effect of plant height on seed yield per plant was low and negative, i.e., the effect of plant height on seed yield per plant was indirect, via the weight of 1,000 seeds $(\mathrm{IE}=0.174)$ and total leaf number per plant $(\mathrm{IE}=0.131)$.

The path analysis showed that total leaf number per plant exhibited a very low positive direct effect on seed oil content $(\mathrm{DE}=0.097)$ and a very high positive direct effect on seed yield per plant $\left(\mathrm{DE}=0.231^{* *}\right)$. The correlation between total leaf number per plant and seed oil content was low and positive $(\mathrm{CC}=0.168)$, same as the direct effect. Total leaf number per plant exhibited a positive indirect effect on seed oil content via head diameter $(\mathrm{IE}=0.313)$ and negative indirect effects via plant height $(\mathrm{IE}=-0.147)$ and stem diameter $(\mathrm{IE}=-0.063)$. The very high positive direct effect of total leaf number per plant on seed yield per plant was masked by its negative indirect effects via most of the studied traits, which explains the very low correlation between total leaf number per plant and seed yield per plant $(C C=0.087)$.

The analysis of path coefficients indicated that stem diameter had a low positive direct effect on seed oil content $(\mathrm{DE}=0.123)$ and seed yield per plant $(\mathrm{DE}=0.129)$ (Figures 3 and 4 ). The very high simple correlation coefficient between stem diameter and seed oil content $\left(\mathrm{CC}=0.419^{* *}\right)$ resulted from high negative indirect effects of stem diameter on seed oil content via head diameter (IE $=-0.445)$ and the weight of 1,000 seeds $(\mathrm{IE}=-0.214)$.

The simple correlation coefficient between stem diameter and seed yield per plant, which was very high and positive $\left(\mathrm{CC}=0.411^{* *}\right)$, resulted from a low positive direct effect of stem diameter on seed yield per plant which was masked by a positive indirect effect of stem diameter on seed yield per plant via the weight of 1,000 seeds $(\mathrm{IE}=0.299)$ and its negative indirect effect via total leaf number per plant (IE=-0.119) (Table 2).

Total leaf area per plant had very low direct effects on seed oil content and seed yield per plant $(\mathrm{DE}=0.052$ and $\mathrm{DE}=0.050$, respectively) (Figures 3 and 4 ). There was a very high negative correlation between total leaf area per plant and seed oil content $\left(\mathrm{CC}=-0.457^{* *}\right)$, which resulted from negative indirect effects of total leaf area per plant on seed oil content via head diameter ( $\mathrm{IE}=0.417$ ), weight of 1,000 seeds $(\mathrm{IE}=-0.161)$ and total leaf number per plant $(\mathrm{IE}=-0.020)$. There was a very high positive correlation between total leaf area per plant and seed yield per plant $\left(\mathrm{CC}=0.623^{* *}\right)$, which resulted from a positive indirect effects of total leaf area per plant on seed yield per plant via the weight of 1000 seeds $(\mathrm{IE}=0.364)$, total seed 


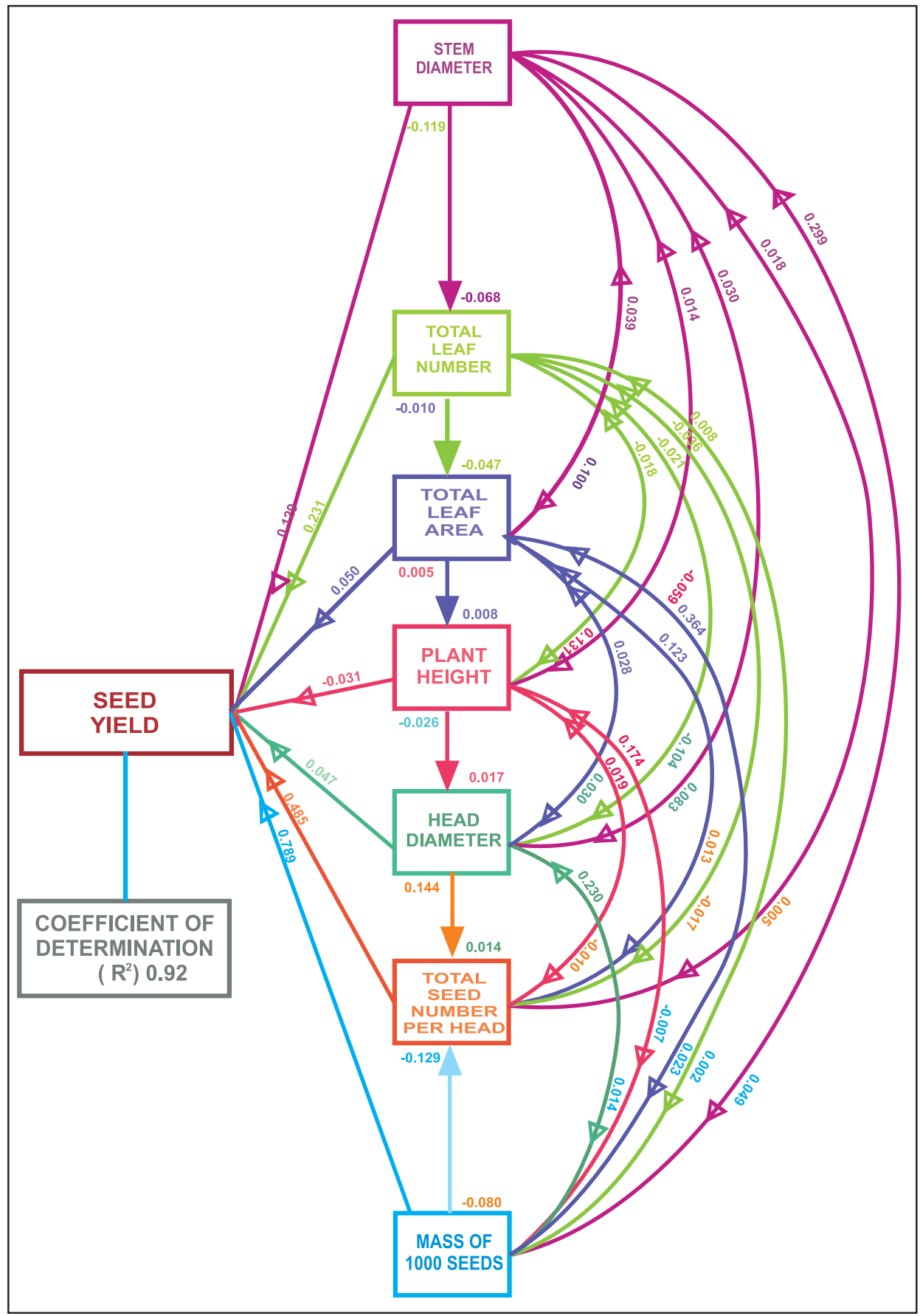

Figure 4: Graphic presentation of the path diagram for seed yield in sunflower $\left(F_{1}\right)$ 
number per head $(\mathrm{IE}=0.123)$ and stem diameter $(\mathrm{IE}=0.100)$. High positive direct effects of total leaf area per plant on seed yield per plant were observed by Razi et al. (1999) and Nirmala et al. (2000).

Table 2: Path coefficient analysis of seed yield and oil content in sunflower.

\begin{tabular}{|c|c|c|c|c|c|c|c|}
\hline \multirow{2}{*}{ Component } & & \multicolumn{3}{|c|}{ SOC } & \multicolumn{3}{|c|}{ SY } \\
\hline & & $\mathrm{DE}(\mathrm{P})$ & IE (Pxr) & $\mathrm{CC}(\mathrm{r})$ & $\mathrm{DE}(\mathrm{P})$ & IE (Pxr) & $\mathrm{CC}(\mathrm{r})$ \\
\hline Stem diameter (STD) & $\mathrm{X} 1$ & 0.123 & & & 0.129 & & \\
\hline Indirect effect TLN & & & -0.050 & & & -0.119 & \\
\hline Indirect effect TLA & & & 0.040 & & & 0.039 & \\
\hline Indirect effect PH & & & 0.119 & & & 0.014 & \\
\hline Indirect effect HD & & & -0.445 & & & 0.030 & \\
\hline Indirect effect TSN & & & 0.008 & & & 0.018 & \\
\hline Indirect effect M1000S & & & -0.214 & & & 0.299 & \\
\hline Total & & & & $-0.419 * *$ & & & $0.411^{* *}$ \\
\hline Total leaf number (TLN) & $\mathrm{X} 2$ & 0.097 & & & $0.231^{\star \star}$ & & \\
\hline Stem diameter STD & & & -0.063 & & & -0.066 & \\
\hline Indirect effect TLA & & & -0.010 & & & -0.010 & \\
\hline Indirect effect PH & & & -0.147 & & & -0.018 & \\
\hline Indirect effect HD & & & 0.313 & & & -0.021 & \\
\hline Indirect effect TSN & & & -0.015 & & & -0.036 & \\
\hline Indirect effect M1000S & & & -0.006 & & & 0.008 & \\
\hline Total & & & & 0.168 & & & 0.087 \\
\hline Total leaf area (TLA) & $\mathrm{X3}$ & 0.052 & & & 0.050 & & \\
\hline Indirect effect STD & & & 0.095 & & & 0.100 & \\
\hline Indirect effect TLN & & & -0.020 & & & -0.047 & \\
\hline Indirect effect PH & & & 0.042 & & & 0.005 & \\
\hline Indirect effect HD & & & -0.417 & & & 0.028 & \\
\hline Indirect effect TSN & & & 0.052 & & & 0.123 & \\
\hline Indirect effect M1000S & & & -0.261 & & & 0.364 & \\
\hline Total & & & & $-0.457^{* *}$ & & & $0.623^{\star *}$ \\
\hline Plant height (PH) & $\mathrm{X} 4$ & $-0.260^{\star}$ & & & -0.031 & & \\
\hline Indirect effect STD & & & 0.056 & & & -0.059 & \\
\hline Indirect effect TLN & & & 0.055 & & & 0.131 & \\
\hline Indirect effect TLA & & & -0.008 & & & -0.008 & \\
\hline Indirect effect HD & & & 0.377 & & & -0.026 & \\
\hline Indirect effect TSN & & & 0.008 & & & 0.019 & \\
\hline Indirect effect M1000S & & & -0.124 & & & 0.174 & \\
\hline Total & & & & -0.009 & & & 0.200 \\
\hline Head diameter (HD) & $\mathrm{X} 5$ & $-0.692^{\star \star}$ & & & 0.047 & & \\
\hline Indirect effect STD & & & 0.079 & & & 0.083 & \\
\hline Indirect effect TLN & & & -0.044 & & & -0.104 & \\
\hline Indirect effect TLA & & & 0.031 & & & 0.030 & \\
\hline Indirect effect PH & & & 0.142 & & & 0.017 & \\
\hline
\end{tabular}


Table 2: Path coefficient analysis of seed yield and oil content in sunflower.

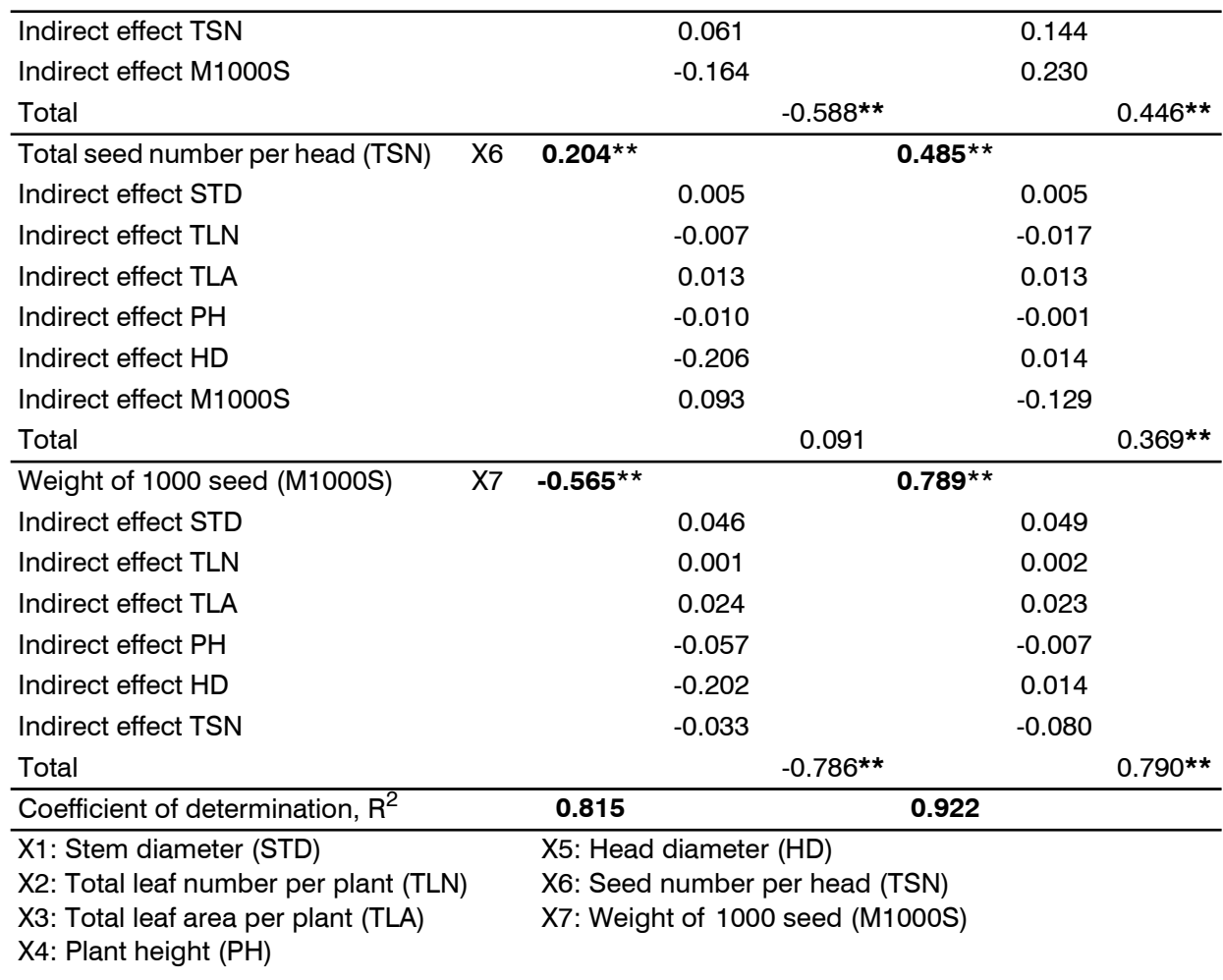

It is important for sunflower breeding for increased productivity to find morphological and physiological traits that are easy to score and at the same time demonstrate causal relationships with seed oil content and seed yield per plant and therefore could be used as selection criteria. The focus should be placed on traits that have a very high positive direct effect on seed yield and oil content.

The path analysis indicated that total seed number per head had high direct effects on seed oil content and seed yield per plant (Figures 1 and 2). Very high positive direct effects on seed yield per plant were exhibited by the weight of 1,000 seeds, total seed number per head and total leaf number per plant. Marinković (1992), Goksoy and Turan (2007) and Behradfar et al. (2009) reported positive direct effects of the weight of 1,000 seeds and total seed number per head on seed yield of sunflower. In our study, highest negative direct effect on seed yield per plant were exhibited by head diameter and the weight of 1,000 seeds (Figures 1 and 2).

Having examined the direct and indirect effects of the group of morphological and physiological traits on seed yield and oil content, we concluded that the direct effects of the stem diameter, total leaf number per plant, total leaf area per plant, plant height, total seed number per head and the weight of 1000 seeds on seed oil content were masked by the high indirect effect of head diameter. The direct effects 
of the stem diameter, total leaf area per plant, plant height, head diameter and total seed number per head on seed yield per plant was masked by the high indirect effect of the weight of 1000 seeds (Table 2).

The coefficients of determination $\left(\mathrm{R}^{2}\right)$ for seed yield and oil content were 0.922 and 0.815 , respectively, which indicated that the studied traits affected $92 \%$ and $82 \%$, respectively, of the total variability for seed yield and oil content (Figures 3 and 4$)$.

Differences in the results obtained in this and other studies may be due to different plant materials used in these studies.

The research results discussed in this paper indicate that, among the studied traits, total number of seeds per head had the largest impact on seed yield and oil content. It can be used in improvement of seed yield and oil content as well as for assessment of sunflower breeding materials.

\section{CONCLUSIONS}

Determination of relationships between seed yield and oil content on the one hand and morphological and physiological traits of the sunflower plant on the other facilitates the utilization of genetic resources in sunflower breeding for a high genetic potential for seed yield.

The analysis of simple correlation coefficients showed that the weight of 1,000 seeds and stem diameter had a high negative correlation with seed oil content and a high positive correlation with seed yield per plant. Further, the total leaf number per plant and total seed number per head had a positive but low correlation with seed oil content and a very high positive correlation with seed yield per plant. Head diameter had a very high negative correlation with seed oil content and a very high positive correlation with seed yield per plant. Plant height had a low negative correlation with seed oil content and a low positive correlation with seed yield per plant.

The applied path coefficient analysis gave a somewhat different picture. It partitioned the direct and indirect effects of the morphological and physiological yield components on seed yield and oil content, which allowed us to detect the components that exhibited the highest direct effects on seed oil content and seed yield expression. Total seed number per head was found to be a good indicator for seed yield and oil content. The data obtained in this investigation, as well as various literature data, indicate that the weight of 1,000 seeds, total seed number per head and total leaf number per plant are the main seed yield components which are applicable as selection criteria in sunflower breeding.

The coefficients of determination $\left(\mathrm{R}^{2}\right)$ of 0.922 and 0.815 indicated that the traits involved in this study affected the total variability of seed yield and oil content by $92 \%$ and $82 \%$, respectively. 


\section{REFERENCES}

Arshad, M., Kasnif Ilias, M., Ayub Khan, M., 2007. Genetic divergence and path coefficient analysis for seed yield traits in sunflower (Helianthus annuus L.) hybrids. Pak. J. Bot. 39(6): 2009-2015.

Ashok, S., Mohamed Sheriff, N., Narayanan, S.L., 2000. Combining ability studies in sunflower (Helianthus annuus L.). Crop Res. (Hisar) 20(3): 457-462.

Behradfar, A., Gorttapeh, H., Zardashty, M.R., Talat, F., 2009. Evaluation correlated traits for seed and oil yieled in sunflower (Helianthus annuus L.) through Path analysis in under conditions relay cropping. Res. J. Biol. Sci. 4(1): 82-85.

Dagustu, N., 2002. Correlations and path coefficient analysis of seed yield components in sunflower (Helianthus annuus L.). Turkish J. Field Crops 7(1): 15-19.

Dewey, D.R., Lu, K.H., 1952. A correlation and path coefficient analysis of component of crested wheatgrass seed production. Agronomy J. 51: 515-518.

Dušanić, N., Miklič, V., Joksimović, J. and Atlagić, J., 2004. Path coefficient analysis of some yield components of sunflower. In: Seiler, G.J. [ed.], Proc. $16^{\text {th }}$ Intl. Sunflower Conf., Fargo, ND, USA, 29 August-4 September 2004. Intl. Sunflower Assoc., Paris, France II: 531-537.

El-Hosary, A., El-Ahmar, B. and El-Kasaby, A.E., 1999. Association studies in sunflower. Helia 22(Special issue): 561-567.

Fick, G.N., Zimmer, D.E. and Zimmerman, D.C., 1974. Correlation of seed and oil content with other plant and seed characteristics. Crop Science 14: 755-757.

Gonzales, J., Mancuso, N. and Oliva, C., 2000. Factores geneticos ambientales y corelaciones entre rendimiento y calidad de girasol. In: Proc. $15^{\text {th }}$ Intl. Sunflower Conf., Toulouse, France, 12-15 June 2000. Intl. Sunflower Assoc., Paris, France II: 105-110.

Göksoy, A.T. and Turan, Z.M., 2007. Correlations and path analysis of yield components in synthetic varieties of sunflower (Helianthus annuus L.). Acta Agronomica Hungarica 55(3): 339-345.

Green, V.E., 1980. Correlation and path analysis of the components of yield in sunflower cultivars (Helianthus annuus L.). In: Proc. $9^{\text {th }}$ Intl. Sunflower Conf., Torremolinos, Spain, 8-13 July 1980. Intl. Sunflower Assoc., Paris, France 1: 12-21.

Habib, H., Mehdi, S.S., Ashfaq Anjum, M., Ehsan Mohyuddin, M., Zafar, M., 2007. Correlation and Path Analysis for Seed Yield in Sunflower (Helianthus annuus L.) under Charcoal Rot (Macrophomina phaseolina) Stress Conditions. Int. J. Agri. Biol. 9(2): 362-364.

Hadživuković, S. 1991. Statistical Methods. $2^{\text {nd }}$ Extended edition, Faculty of Agriculture, Novi Sad, (in Serbian).

Hladni, N., Škorić, D. and Kraljević-Balalić, M., 2001. Relationship between sunflower seed yield and yield components. In: Malešević, M. [ed.] Book of Proceedings, $1^{\text {st }}$ International Symposium "Food in the $21^{\text {st }}$ Century". Subotica, Serbia and Montenegro 1: 162-167.

Hladni, N., Škorić, D. and Kraljević-Balalić, M., 2003. Components of phenotypic variability for head diameter in sunflower (Helianthus annuus L.). Genetika 35(2): 67-75.

Hladni, N., Škorić, D., Kraljević-Balalić, M., Ivanović, M., Sakač, Z. and Jovanović D., 2004. Correlation of yield components and seed yield per plant in sunflower (Helianthus annuus L.). In: Seiler, G.J. [ed.], Proc. 16 ${ }^{\text {th }}$ Intl. Sunflower Conf., Fargo, ND, USA, 29 August-4 September 2004. Intl. Sunflower Assoc., Paris, France. II: 491-496.

Hladni, N., Škorić, D., Kraljević-Balalić, M., Sakač, Z., Jovanović, D., 2006. Combining ability for oil content and its correlations with other yield components in sunflower (Helianthus annuus L.). Helia 29(44): 101-110.

Hladni, N., Jocić, S., Miklič, V., Mijić, A., Saftić-Panković, D., Kraljević-Balalić, M., 2008. Direct and indirect effects of morphophysiological traits on oil yield of sunflower (Helianthus annuus L.). In: Kobiljski, B. [ed], Proc. $1^{\text {st }}$ Int. Conf. "Conventional and Molecular Breeding of Field and Vegetable Crops”, Novi Sad, Serbia, 1: 491-494.

Ivanović, M., Rosić, K., 1985. Path coefficient analysis for three stalk traits and grain yield in maize (Zea mays L.). Maydica, XXX: 233-239.

Khan, A.L., Ullah, S., Murtaza, B., Khan, M.Y., 2003. Variability and correlation study in different newly developed sunflower hybrids. Asian J. Plant. Sci. 2(12): 887-890.

Lal, G.S., Bhadoriya, V.S., Singh, A.K., 1997. Genetic association and path analysis in elite lines of sunflower. Crop Research 13: 631-634. 
Marinković, R., 1987. Analiza komponenti prinosa semena suncokreta (Helianthus annuus L.) koeficijentom putanje I. Apstr. III Kongres genetičara Jugoslavije sa međunarodnim učešćem, Ljubljana, Jugoslavija, pp. 95.

Marinković, R. and Škorić, D., 1988. Path-coefficient analysis of components of sunflower seed yield (H. annuus L.). In: Proc $12^{\text {th }}$ Intl. Sunflower Conf., Novi Sad, Yugoslavia, 25-29 July 1988. Intl. Sunflower Assoc., Paris, France 1: 406-407.

Marinković, R., 1992. Path-coefficient analysis of some yield components of sunflower (Helianthus annuus L.). Euphytica 60: 201-205.

Marinković, R., Škorić, D., Nenadić, N., Jovanović, D., Miklič, V., Joksimović, J., Stanojević, D., Nedeljković, S., 1994. The influence of seed position in the head on the sunflower $(H$. annuus L.) seed yield and some yield components. Periodicals of Institute of Field and Vegetable Crops Novi Sad 22: 379-389.

Merrien, A., Blanchet, R., Gelfi, N., Rellier, J.P. and Rollier, M., 1982. Voises d elaboration ru rendement chez le tournesol sous differents stress hidriques. In: Proc. $10^{\text {th }}$ Intl. Sunflower Conf., Surfers Paradise, Australia, 14-18 Mar 1982. Intl. Sunflower Assoc., Paris, France II: 1-14.

Mijić, A., Krizmanić, M., Guberac, V., Marić, S., 2006. Path coefficient analysis of several components oil yield in sunlower (Helianthus annuus L.). Poljoprivreda/Agriculture (Osijek) 12(1): 11-15.

Miklič, V., Škorić, D., Balalić, I., Jocić, S., Jovanović, D., Marinković, R., Hladni, N., Joksimović, J., Gvozdenović, S., 2007. Test results of NS sunflower hybrids in trials and recommendations for sowing in 2007. Periodicals of Institute of Field and Vegetable Crops ,Novi Sad 43: 115-127.

Miklič, V., Hladni, N., Jocić, S., Marinković, R., Atlagić, J., Saftić-Panković, D., Miladinović, D., Dušanić, N. and Gvozdenović, S., 2008. Sunflower Breeding at Institute of Field and Vegetable Crops. Periodicals of Institute of Field and Vegetable Crops, Novi Sad 45(1): 31-63.

Miklič, V., Balalić, I., Jocić, S., Marinković, R., Cvejić, S., Hladni, N., Miladinović, D., 2010. Stability estimation for seed and oil yield of NS sunflower hybrids in small-plot trials and recommendation for 2010 sowing season. Field Veg. Crop. Res., 47(1): 131-146.

MSTAT-C, 1991. Version 2.1., 384C Plant and Soil Sciences, Michigan State University East Lansing, MI 48824.

Nirmala, V.S., Gopalan, A., Sassikumar. D., 2000. Correlation and path-coefficient analysis in sunflower (Helianthus annuus L.). Madras Agric. J., 86(4/6): 269-272.

Ozer, H., Erdogon, O. and Taskin, P., 2003. Determination of the agronomic performance of some oilseed sunflower hybrids grown under Erzurum ecological conditions. Turk. J. Agric. 27: 199-205.

Patil, B.R., Rudradhya, M., Vijayakumar, C.H.M., Basappa, H. and Kulkarni, R.S., 1996. Correlations and path coefficient analysis in sunflower. J. of Oil Seeds Research, 13(2): 162-166.

Punnia, M.S. and Gill, H.S., 1994. Correlations and path coefficient analysis for seed yield traits in sunflower (Helianthus annuus L.). Helia 17(20): 7-12.

Razi, H., Assad, M.T., 1999. Comparison of selection criteria in normal and limited irrigation in sunflower. Euphytica 105: 83-90.

Sarno, R., Leto, C., Carrubba, A., Cibella, R., 1992. Correlation between some yield factors in sunflower. In: Proc. 13 ${ }^{\text {th }}$ Intl. Sunflower Conf., 7-11 September 1992, Pisa Italy. Intl. Sunflower Assoc., Paris, France I: 366-389.

Seiler, G.J., 1992. Utilization of wild sunflower species for the improvement of cultivated sunflower. Field Crops Res. 30: 195-230.

Thitiporn, M. and Chiraporn, S., 2008. Correlation and path coefficient analysis on seed yield in sunflower. Suranaree J. Sci. Technol. 15(3): 243-248.

Škorić, D., 1974. Correlation among the most important characters of sunflower in $\mathrm{F}_{1}$ generation. In: Proc. $6^{\text {th }}$ Intl. Sunflower Conf., Bucharest, Romania, 22-24 July 1974. Intl. Sunflower Assoc., Paris, France I: 283-289.

Škorić, D., Jocić, S., Hladni, N. and Vannozzi, G.P., 2007. An analysis of heterotic potential for agronomically important traits in sunflower (Helianthus annuus L.). Helia 30(46): 55-73.

Taklewold, A., Jayaramaiah, H., Jagadeesh, B.N., 2000. Correlations and path analysis of physio-morphological characters of sunflower (Helianthus annuus L.) as related to breeding method. Helia 23(32): 105-114. 
Vasin, J., Sekulić, P. and Belić, M., 2002. Characteristics of the chernozem soil at Rimski Šančevi experiment field of Institute of Field and Vegetable Crops. Sesiunea anuala omagiala de comunicari stiintifice "80 de ani da la nasterea prof. dr. doc. St. Iulian Dracea", USAMV a Banatului Timisoara, 9-10 mai, Editura Orizonturi Universitare Timisoara, (ISBN 973-8391-23-7) 34:153-160

Wright, S., 1921. Correlation and causation. J. Agric. Res. I(20): 557-585.

Yalcin, K., Goksel, E., Sezgin, D., Veli, P., Tahir, G., 2007. Determining the relationships between yield and yield attributes in sunflower. Turk. J. Agric. 31: 237-244. 
